\title{
Clinical, Histopathological and Outcome Analysis of Five Patients With Lichenoid Eruption Following Anti-Tumor Necrosis Factor-Alpha Therapy for Ankylosing Spondylitis: Report of One Case and Review of the Literature
}

Samily Cordeiro De Oliveira ${ }^{1}$, Antonio Helder Costa Vasconcelos ${ }^{2}$, Emmanuel Pereira Benevides Magalhães $^{3}$, Fernanda Judith Vieira Corrêa ${ }^{4}$, Carlos Ewerton Maia Rodrigues ${ }^{5,6}$

1. Medicine, Federal University of Ceará, Fortaleza, BRA 2. Medicine, University of Fortaleza, Fortaleza, BRA 3. Dermatology, University of Fortaleza, Fortaleza, BRA 4. Pathology, Haroldo Juaçaba Hospital, Fortaleza, BRA 5. Rheumatology, Federal Universiity of Ceará, Fortaleza, BRA 6. Rheumatology, University of Fortaleza, Fortaleza, BRA

Corresponding author: Carlos Ewerton Maia Rodrigues, carlosewerton@hotmail.com

\begin{abstract}
Tumor necrosis factor-alpha (TNF-a) inhibitors have become the mainstay of therapy for a wide range of autoinflammatory diseases, despite concerns regarding dermatological adverse reactions. In this paper, we describe the clinical and histological findings and outcome of a case of lichenoid eruption (LE) following adalimumab therapy for ankylosing spondylitis (AS) and review four earlier reports concerning this rare clinical association. The time of onset varied considerably (three weeks to 52 months) and lesions varied within the clinical spectrum (from typical lichen planus to psoriasiform), but all had LE-compatible histology, with acanthosis, necrotic keratinocytes and lymphocytic infiltrate as hallmarks. Most patients (3/5) improved with treatment and one experienced full recovery, while in one case the lesions persisted. TNF- $a$ has been implicated in the pathogenesis of lichen planus, making it difficult to explain how TNF- $a$ antagonists can induce lichenoid reactions. The appearance of LE may in some cases justify cessation of therapy.
\end{abstract}

Categories: Dermatology, Pathology, Rheumatology

Keywords: anti tnf, lichen planus, ankylosing spondylitis

\section{Introduction}

Tumor necrosis factor-alpha (TNF $\alpha$ ) inhibitors are the mainstay of therapy for a wide range of autoimmune diseases. In patients with ankylosing spondylitis (AS), TNF $\alpha$ inhibitors have been shown to effectively bring symptoms under control, improve quality of life as well as reducing radiographic progression, especially with early initiation and longer duration of follow up [1].

Received 12/26/2019

Review began 12/29/2019 Review ended 09/19/2020 Published 09/22/2020

\section{() Copyright 2020}

Oliveira et al. This is an open access article distributed under the terms of the Creative Commons Attribution License CC-BY 4.0., which permits unrestricted use, distribution, and reproduction in any medium, provided the original author and source are credited.
TNF inhibitors appear to reduce radiographic progression in AS, Though relatively safe, TNF $\alpha$ inhibitors have been associated with various side effects, including a spectrum of skin lesions. In fact, dermatological reactions are not uncommon when TNF $\alpha$ inhibitors are used to treat autoimmune conditions, such as AS, rheumatoid arthritis (RA), Crohn's disease and even psoriasis and psoriatic arthritis. Most published reports are descriptions of paradoxical psoriasiform eruptions, but other reactions are also well documented (e.g., granuloma annulare, cutaneous lupus and lupus-like syndromes) [1-3] and there is a small but increasing number of reports associating TNF $\alpha$ inhibitors with the onset of lichenoid eruption (LE) [1, 2].

The pathogenesis of LE is still not fully understood, with some considering it paradoxical $[1,4]$. In this context, lichen planus induced by TNF $\alpha$ inhibitors has been observed in some types of spondyloarthritis [5, 6]. Indeed, this is supported by a study involving 252 patients with RA and 183 with spondyloarthropathy treated with TNF $\alpha$ inhibitors and evaluated for immune-mediated skin lesions. Only one patient in each disease group developed LE [1].

In this paper we describe the clinical presentation and histopathological findings of LE following adalimumab therapy for ankylosing spondylitis along with a review of more four cases of this rare association.

\section{Case Presentation}

A 54-year-old housewife of mixed race presented with chronic back pain, mainly on the left side, with radiation to the inferior left limb. The patient had hypertension, smoking and depression as comorbidities. The patient tested negative for human leukocyte antigen B27 (HLA-B27). Due to persistent symptoms of back pain and morning rigidity of up to two hours, associated with bilateral hip pain and increased C- 


\section{Cureus}

reactive protein (CRP) levels, the patient was referred to the rheumatologist, and a pelvic MRI (dated $3 / 29 / 16$ ) was requested; it showed signs of inflammatory sacroiliitis activity, and bilateral sacroiliitis was visible on a pelvic $x$-ray $(9 / 15 / 2016)$. The patient was prescribed non-steroidal anti-inflammatory drugs (NSAIDs) and muscle relaxants, but the pain persisted. Four years after the onset of the inflammatory symptoms, anti-TNFa therapy with adalimumab was initiated.

The clinical response was good (Bath Ankylosing Disease Activity Index [BASDAI] reduced to $<4$ in a period of six months). However, after six months of treatment with adalimumab, the patient developed flat polygonal erythemato-violaceous papules and plaques on the extremities (arms and legs) with Wickham striae, but no oral lesions (Figure 1). Adalimumab was promptly discontinued and replaced with secukinumab, an interleukin (IL)-17 inhibitor. One month later, the lesions changed to pruriginous hyperchromic macules of increasing size on the left arm, and an erythematous plaque developed on the posterior left neck. Based on the diagnostic hypothesis of lichen planus, the patient was prescribed topical clobetasol, prednisone ( $40 \mathrm{mg} / \mathrm{day}$, tapered) and hydroxyzine. At an encounter two months later, the pruritus had resolved and the erythematoviolaceous plaques had improved, leaving residual hyperchromic lesions, especially in sun-exposed areas. Clobetasol therapy was continued for active lesions, with the addition of hydroquinone. Dexamethasone was prescribed in order to improve the cosmetic appearance of the macules.

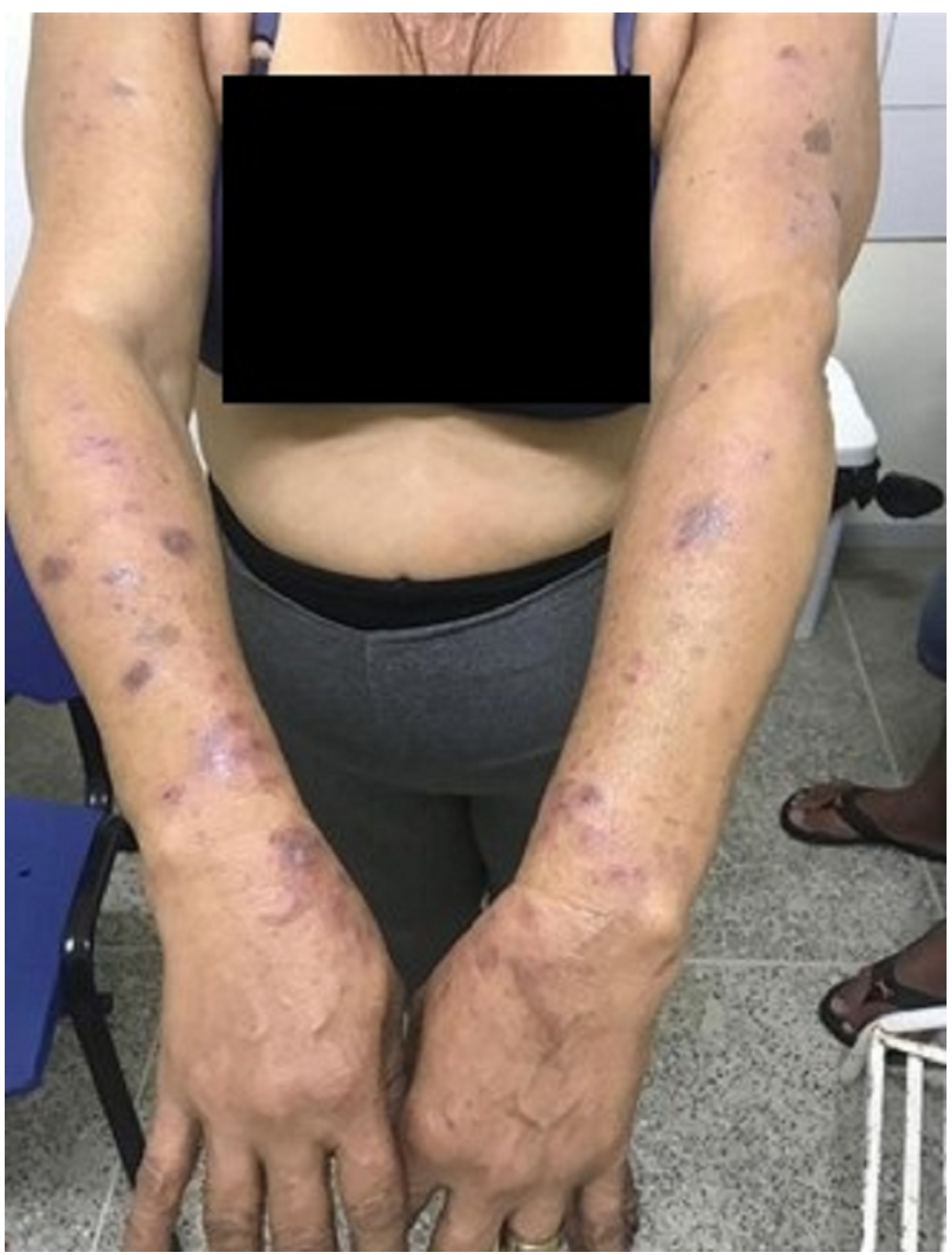

FIGURE 1: Flat polygonal papules and plaques with Wickham striae, leaving hyperchromic macules, sparing the trunk 


\section{Cureus}

The anatomopathological analysis confirmed the diagnosis of chronic lichenoid dermatitis (Figure 2) compatible with LE.

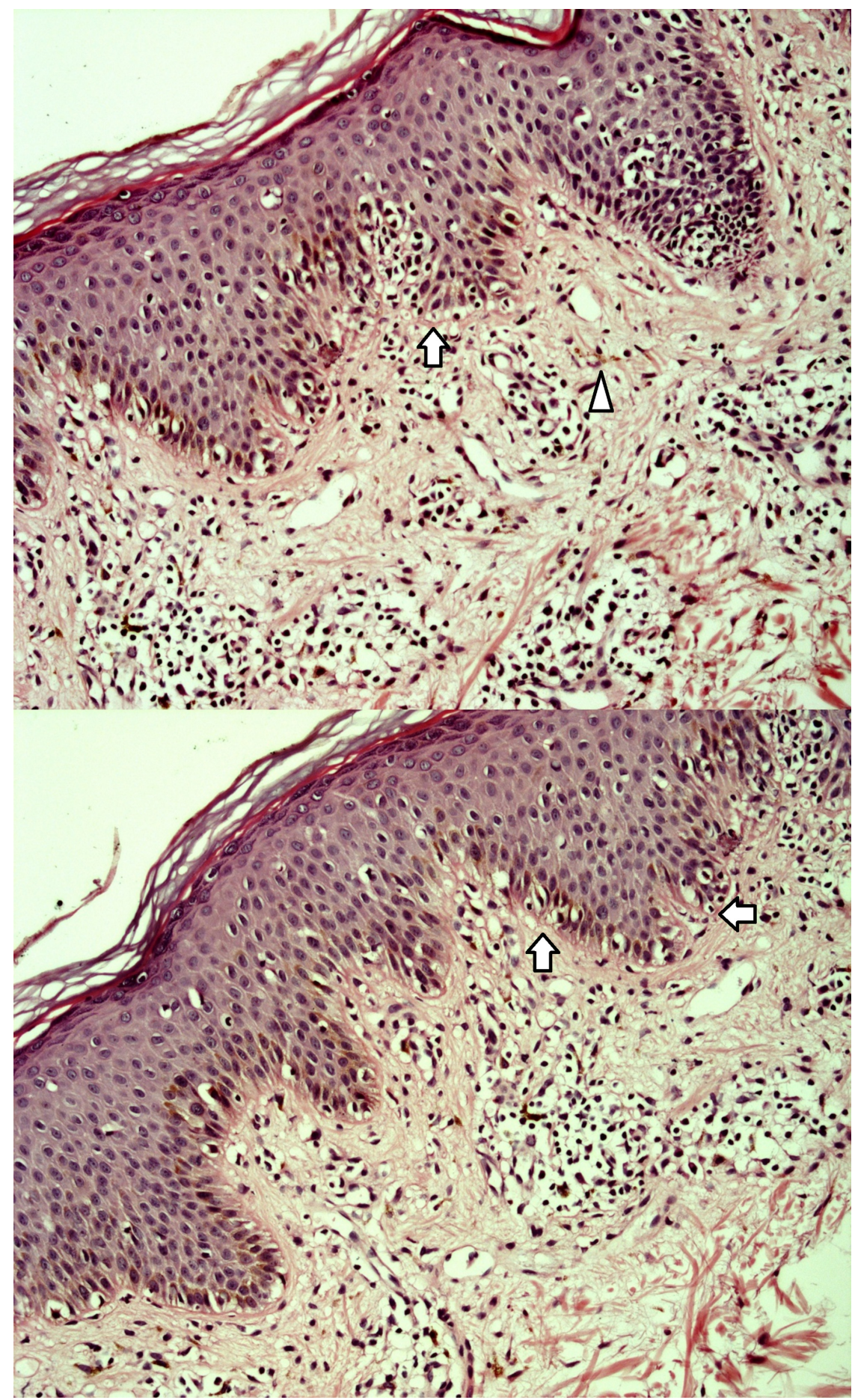

FIGURE 2: Histological skin samples showing discrete irregular acanthosis, hyperkeratosis, vacuolar degeneration of the basal layer, round bodies, band normolimphocytic inflammatory infiltrate and pigmentary effusion

Arrow: bandlike chronic inflammatory infiltrate; triangle: pigmentary effusion (stain: H\&E, 200x magnification)

\section{Discussion}

The present case of LE in a patient receiving anti-TNFa therapy for AS is a relevant addition to the four 
cases previously described [1, 7-9] (Table 1), the first of which was reported as recently as 2002 [7]. To our knowledge, this is the first article to review the clinical and histopathological findings and outcome of all known cases.

\begin{tabular}{|c|c|c|c|c|c|c|c|c|}
\hline Study & $\begin{array}{l}\text { Patient } \\
\text { age, } \\
\text { y/sex }\end{array}$ & Drug & Reaction site & morphology & reaction & Histopathology & $\begin{array}{l}\text { Cessation } \\
\text { of TNF } \\
\text { inhibitor }\end{array}$ & Outcome \\
\hline $\begin{array}{l}\text { Exarchou } \\
\text { et al [1] } \\
2009\end{array}$ & - & Infliximab & - & - & - & - & No & $\begin{array}{l}\text { Treated with local } \\
\text { corticosteroids } \\
\text { with good results - } \\
\text { Improvement }\end{array}$ \\
\hline $\begin{array}{l}\text { Vergara et } \\
\text { al. [7] } \\
2002\end{array}$ & 60/M & Infliximab & $\begin{array}{l}\text { Cutaneous arm } \\
\text { flexor }\end{array}$ & $\begin{array}{l}\text { Erythematous } \\
\text { papules, some } \\
\text { polygonal in shape }\end{array}$ & 3 wks & $\begin{array}{l}\text { Necrotic keratinocytes, focal detachment of } \\
\text { dermoepidermal junction, intense bandlike } \\
\text { inflammatory infiltrate of lymphocytes, histocytes } \\
\text { in the superficial dermis }\end{array}$ & Yes & $\begin{array}{l}\text { Complete } \\
\text { improvement - } \\
\text { Recovery }\end{array}$ \\
\hline $\begin{array}{l}\text { Wendling } \\
\text { et al. [8] } \\
2013\end{array}$ & 47/M & Adalimumab & $\begin{array}{l}\text { Legs, forearms } \\
\text { and the perineal } \\
\text { region + oral } \\
\text { involvement }\end{array}$ & $\begin{array}{l}\text { Pruriginous shiny, } \\
\text { firm and reddish } \\
\text { purple skin lesions }\end{array}$ & $52 \mathrm{mo}$ & $\begin{array}{l}\text { Histopathological findings consistent with the } \\
\text { diagnosis of lichen planus }\end{array}$ & $\begin{array}{l}\text { Yes, } \\
\text { change to } \\
\text { infliximab }\end{array}$ & $\begin{array}{l}\text { Skin evolution was } \\
\text { favorable under } \\
\text { topical and oral } \\
\text { steroids - } \\
\text { Improvement }\end{array}$ \\
\hline $\begin{array}{l}\text { Seneschal } \\
\text { et al. [9] } \\
2007\end{array}$ & $26 / \mathrm{F}$ & Infliximab & - & $\begin{array}{l}\text { Plaques and } \\
\text { widespread } \\
\text { guttate psoriasis- } \\
\text { like eruptions }\end{array}$ & $8 \mathrm{mo}$ & $\begin{array}{l}\text { Parakeratosis, acanthosis, IIchenold and } \\
\text { spongiotic pattern, necrotic keratinocytes }\end{array}$ & Yes & $\begin{array}{l}\text { Persistent skin } \\
\text { lesions in spite of } \\
\text { cessation of } \\
\text { infliximab for one } \\
\text { year - Continuity }\end{array}$ \\
\hline $\begin{array}{l}\text { Current } \\
\text { case }\end{array}$ & $54 / \mathrm{F}$ & Adalimumab & $\begin{array}{l}\text { Cutaneous neck } \\
\text { and limbs }\end{array}$ & $\begin{array}{l}\text { Erythematonodular } \\
\text { plaques }\end{array}$ & $6 \mathrm{mo}$ & $\begin{array}{l}\text { Discrete irregular acanthosis, hyperkeratosis, } \\
\text { vacuolar degeneration of the basal layer, round } \\
\text { bodies, band normolimphocytic inflammatory } \\
\text { infiltrate and pigmentary effusion }\end{array}$ & Yes & $\begin{array}{l}\text { Residual } \\
\text { hyperchromic } \\
\text { spots - } \\
\text { Improvement }\end{array}$ \\
\hline
\end{tabular}

TABLE 1: Reported lichenoid reactions in patients with ankylosing spondylitis following therapy with TNFa inhibitors

TNFa: tumor necrosis factor-a

AS is commonly treated with TNFa inhibitors, despite the risk of adverse effects. LE is rarely reported. The five known cases of TNFa inhibitor-induced LE in AS patients include two males, two females and one individual of unspecified sex, with a median age of 43 years (range: 26-60). LE was caused by treatment with adalimumab or infliximab, but patients with other conditions are known to have developed LE after using etanercept and lenercept, suggesting the reaction is not limited to a specific drug but is a characteristic of the class $[10,11]$. The time of onset of LE ranged from three weeks to 52 months of drug use.

Lesions were located mostly on the arms and/or legs, but two patients also reported oral involvement. Lesions were described as "erythematonodular plaques", "erythematous papules, some polygonal in shape" [7], "pruriginous shiny, firm and reddish purple skin lesions" [8], and "plaques and widespread guttate psoriasis-like eruptions" [9]. One patient had perianal lesions. All diagnoses were confirmed by histology, but with variations within the clinical spectrum: lesions were typical of lichen planus, non-specific maculopapular morphology or even psoriasis-like [4, 9]. The histological findings were: "necrotic keratinocytes" [7, 9], "parakeratosis, acanthosis" [9], "focal detachment of the dermoepidermal junction and inflammatory infiltrate of lymphocytes" [7] and "degeneration of the basal layer, round bodies".

In three patients (including the current case) anti-TNF $\alpha$ therapy was discontinued due to intense LE-related discomfort. One patient replaced the medication with another drug of the anti-TNF $\alpha$ class, curiously without recurrence of LE [8]. In the current case, anti-TNF $\alpha$ therapy was replaced with anti-IL17 therapy (secukinumab). The cutaneous outcome was mostly good: three of five patients showed improvement and one had full recovery, but in one patient the lesions persisted, even one year after infliximab was stopped. All five patients used topical corticosteroids to treat the skin lesions.

The pathogenesis of lichenoid lesions associated with the use of TNF inhibitors has not yet been fully 
explained. The development of this reaction is somewhat surprising since TNF $\alpha$ is itself involved in the pathogenesis of lichen planus, and TNF $\alpha$ inhibitors have been used with success to treat refractory cases, making it a paradoxical manifestation [12-13].

Some have hypothesized that LE develops due to cross-regulation between type I IFN (interferon) and TNF $\alpha$ in such a manner that the cytokines neutralize each other in a delicate balance. If this were the case, druginduced inhibition of TNF- $\alpha$ would greatly raise the levels of type I INF, inducing the activation of T cells and dendritic cells and producing an inflammatory response favoring the appearance of lesions in genetically predisposed individuals. Thus, TNF- $\alpha$ inhibition may be considered both antiinflammatory and proinflammatory [13-15]. The process may also be modulated by other, as yet unidentified environmental factors.

To test this hypothesis, a blood sample was taken from a patient with LE after a period of adalimumab use and determined the IFN $\alpha$ concentration by enzyme-linked immunosorbent assay in a culture of supernatants from a lymphocyte stimulation test using peripheral blood mononuclear cells. In support of the theory, IFN $\alpha$ levels were greatly increased in the sample; nevertheless, more investigations are required to confirm this finding [14].

Patients with other (non-AS) conditions have also developed LE after anti-TNF $\alpha$ inhibition. Thus, a search of the literature identified 39 patients with other rheumatological diseases (RA n=14, psoriasis/psoriatic arthrithis $n=12$, Sjögren syndrome $n=1$, Crohn's disease $n=7$, unspecific colitis $n=1$, idiopathic juvenile arthrithis $n=2$, and Behçet's disease $n=1$ ) [4-7, 9-11, 14-20] (Table 2). The time from the initiation of the TNF- $\alpha$ blockade to the appearance of LE (when cited) ranged from three weeks to 48 months, although onset within the first two months of therapy was the most common. The tardiest reaction reported was that of a 19-year-old patient treated for juvenile idiopathic arthritis who presented itchy erythematous papular rash over the trunk and limbs after 48 months of infliximab monotherapy, with histology showing focally vacuolated dermatitis of the dermo-epidermal interface and irregular acanthosis and hypergranulosis compatible with LE. Response to steroid therapy was satisfactory and infliximab was replaced with adalimumab, without recurrence of skin lesions [6].

\begin{tabular}{|c|c|c|c|c|c|}
\hline Disease & $\begin{array}{l}\text { Number } \\
\text { of cases }\end{array}$ & Drugs & $\begin{array}{l}\text { Time to } \\
\text { reaction }\end{array}$ & $\begin{array}{l}\text { Cessation of } \\
\text { drug therapy }\end{array}$ & Outcome \\
\hline $\begin{array}{l}\text { Rheumatoid arthritis [7, 9-11, } \\
14-16]\end{array}$ & 14 & $\begin{array}{l}\text { Etanercept Infliximab } \\
\text { Lenercept Adalimumab }\end{array}$ & $\begin{array}{l}3 \text { wks - } 18 \\
\text { mo }\end{array}$ & $\begin{array}{l}\text { Yes (10)/ No } \\
\text { (4) }\end{array}$ & $\begin{array}{l}\text { Improvement (2) / } \\
\text { Recovery (7) }\end{array}$ \\
\hline Severe psoriasis $[4,15-17]$ & 7 & $\begin{array}{l}\text { Etanercept Infliximab } \\
\text { Adalimumab }\end{array}$ & $\begin{array}{l}5 \text { wks - } 11 \\
\text { mo }\end{array}$ & Yes (3)/ No(3) & $\begin{array}{l}\text { Improvement (3) / } \\
\text { Recovery (2) / Continuity } \\
\text { (2) }\end{array}$ \\
\hline $\begin{array}{l}\text { Psoriatic arthritis (with or } \\
\text { without psoriasis) }[5,9,15,16]\end{array}$ & 5 & $\begin{array}{l}\text { Etanercept Infliximab } \\
\text { Adalimumab }\end{array}$ & $\begin{array}{l}1-26 \\
\text { months }\end{array}$ & Yes (3)/ No (1) & $\begin{array}{l}\text { Improvement (2) / } \\
\text { Recovery (2) }\end{array}$ \\
\hline IBD [15-20] & 8 & $\begin{array}{l}\text { Etanercept Infliximab } \\
\text { Certolizumab pegol } \\
\text { Adalimumab }\end{array}$ & $\begin{array}{l}3 \text { weeks - } \\
24 \text { months }\end{array}$ & Yes (4)/ No (3) & $\begin{array}{l}\text { Improvement (2) / } \\
\text { Recovery (4) / Continuity } \\
\text { (1) }\end{array}$ \\
\hline JIA $[6,15]$ & 2 & Adalimumab, Infliximab & $\begin{array}{l}3-48 \\
\text { months }\end{array}$ & Yes & $\begin{array}{l}\text { Improvement (1) / } \\
\text { Recovery (1) }\end{array}$ \\
\hline Behçet's disease [15] & 1 & Adalimumab & 12 months & No & Improvement \\
\hline Sjögren syndrome [16] & 1 & Infliximab & $\begin{array}{l}\text { Not } \\
\text { reported }\end{array}$ & Yes & Improvement \\
\hline
\end{tabular}

TABLE 2: Reported lichenoid reactions in patients with other (non-AS) conditions following therapy with TNFa inhibitors.

JIA: juvenile idiopathic arthritis; IBD: inflammatory bowel disease; TNFa: tumor necrosis factor-a; AS: ankylosing spondylitis

\section{Conclusions}

In conclusion, a growing body of evidence suggests that TNF-a inhibitors can trigger a wide variety of inflammatory states, including lichen planus-like cutaneous and mucosal eruptions. Fortunately, these eruptions have good prognosis. If the patient develops LE, the decision to discontinue therapy should be made on a case-by-case basis, as evidences are scarce. In any case, adverse clinical manifestations should be 


\section{Additional Information Disclosures}

Human subjects: Consent was obtained by all participants in this study. Conflicts of interest: In compliance with the ICMJE uniform disclosure form, all authors declare the following: Payment/services info: All authors have declared that no financial support was received from any organization for the submitted work. Financial relationships: All authors have declared that they have no financial relationships at present or within the previous three years with any organizations that might have an interest in the submitted work. Other relationships: All authors have declared that there are no other relationships or activities that could appear to have influenced the submitted work.

\section{References}

1. Exarchou SA, Voulgari PV, Markatseli TE, Zioga A, Drosos AA: Immune-mediated skin lesions in patients treated with anti-tumour necrosis factor alpha inhibitors. Scand J Rheumatol. 2009, 38:328-31. 10.1080/03009740902922612

2. Mocci G, Marzo M, Papa A, Armuzzi A, Guidi L: Dermatological adverse reactions during anti-TNF treatments: focus on inflammatory bowel disease. J Crohns Colitis. 2013, 7:769-79. 10.1016/j.crohns.2013.01.009

3. Lee HH, Song IH, Friedrich M, et al.: Cutaneous side-effects in patients with rheumatic diseases during application of tumour necrosis factor-alpha antagonists. Br J Dermatol. 2007, 156:486-91. 10.1111/j.13652133.2007.07682.x

4. Asarch A, Gottlieb AB, Lee J, et al.: Lichen planus-like eruptions: an emerging side effect of tumor necrosis factor- $\alpha$ antagonists. J Am Acad Dermatol. 2009, 61:104-11. 10.1016/j.jaad.2008.09.032

5. Garcovich S, Burlando M, Rongioletti F, Garcovich A, Parodi A, Amerio P: Cutaneous drug eruption with an interface dermatitis pattern due to anti-tumour necrosis factor-alpha agents: a relevant class-effect. Acta Derm Venereol. 2010, 90:311-2. 10.2340/00015555-0839

6. Pontikaki I, Shahi E, Frasin LA, Gianotti R, Gelmetti C, Gerloni V, Mero PL: Skin manifestations induced by TNF-alpha inhibitors in juvenile idiopathic arthritis. Clin Rev Allergy Immunol. 2012, 42:131-4. 10.1007/s12016-011-8262-2

7. Vergara G, Silvestre JF, Betlloch I, Vela P, Albares MP, Pascual JC: Cutaneous drug eruption to infliximab: report of 4 cases with an interface dermatitis pattern. Arch Dermatol. 2002, 138:1258-9.

8. Wendling D, Biver-Dalle C, Vidon C, Prati C, Aubin F: Lichen planus under anti TNF therapy for ankylosing spondylitis. Joint Bone Spine. 2013, 80:227-8.

9. Seneschal J, Lepreux S, Bouyssou-Gauthier ML, et al.: Psoriasiform drug eruptions under anti-TNF treatment of arthritis are not true psoriasis. Acta Derm Venereol. 2007, 87:77-80. 10.2340/00015555-0193

10. Barrientos N, García-Sánchez S, Domínguez JD: Letter: lichenoid eruption induced by etanercept . Dermatol Online J. 2012, 18:15.

11. Flendrie M, Vissers WH, Creemers MC, de Jong EM, de Kerkhof PC, van Riel PL: Dermatological conditions during TNF-alpha-blocking therapy in patients with rheumatoid arthritis: a prospective study. Arthritis Res Ther. 2005, $7: 666-76.10 .1186 / \operatorname{ar} 1724$

12. Holló P, Szakonyi J, Kiss D, Jokai H, Horváth A, Kárpati S: Successful treatment of lichen planus with adalimumab. Acta Derm Venereol. 2012, 92:385-6. 10.2340/00015555-1249

13. de Padilla CM, Niewold TB: The type I interferons: basic concepts and clinical relevance in immunemediated inflammatory diseases.. Gene. 2016, 576(1 Pt 1):14-21. 10.1016/j.gene.2015.09.058

14. Inoue A, Sawada Y, Yamaguchi T, et al.: Lichenoid drug eruption caused by adalimumab: a case report and literature review. Eur J Dermatol. 2017, 27:69-70. 10.1684/ejd.2016.2898

15. McCarty M, Basile A, Bair B, Fivenson D: Lichenoid reactions in association with tumor necrosis factor alpha inhibitors: a review of the literature and addition of a fourth lichenoid reaction. J Clin Aesthet Dermatol. 2015, 8:45-9.

16. Jayasekera PS, Walsh ML, Hurrell D, Parslew RA: Case report of lichen planopilaris occurring in a pediatric patient receiving a tumor necrosis factor $\alpha$ inhibitor and a review of the literature. Pediatr Dermatol. 2016, 33:143-6. 10.1111/pde.12768

17. Darrigade AS, Goussot JF, Milpied B, Taieb A, Seneschal J: Pigmented lichenoid drug eruption: a new clinical presentation of interface dermatitis induced by anti-TNF alpha drugs. Eur J Dermatol. 2016, 26:633-4. 10.1684/ejd.2016.2860

18. Andrade P, Lopes S, Albuquerque A, Osório F, Pardal J, Macedo G: Oral lichen planus in IBD patients: a paradoxical adverse effect of anti-TNF- $\alpha$ therapy. Dig Dis Sci. 2015, 60:2746-9. 10.1007/s10620-015-3680-2

19. El Habr C, Meguerian Z, Sammour R: Adalimumab-induced lichenoid drug eruption. J Med Liban. 2014, 62:238-40. 10.12816/0008295

20. Mocciaro F, Orlando A, Renna S, Rizzuto MS, Cottone M: Oral lichen planus after certolizumab pegol treatment in a patient with Crohn's disease. J Crohn's Colitis. 2011, 5:173-4. 10.1016/j.crohns.2011.01.003 